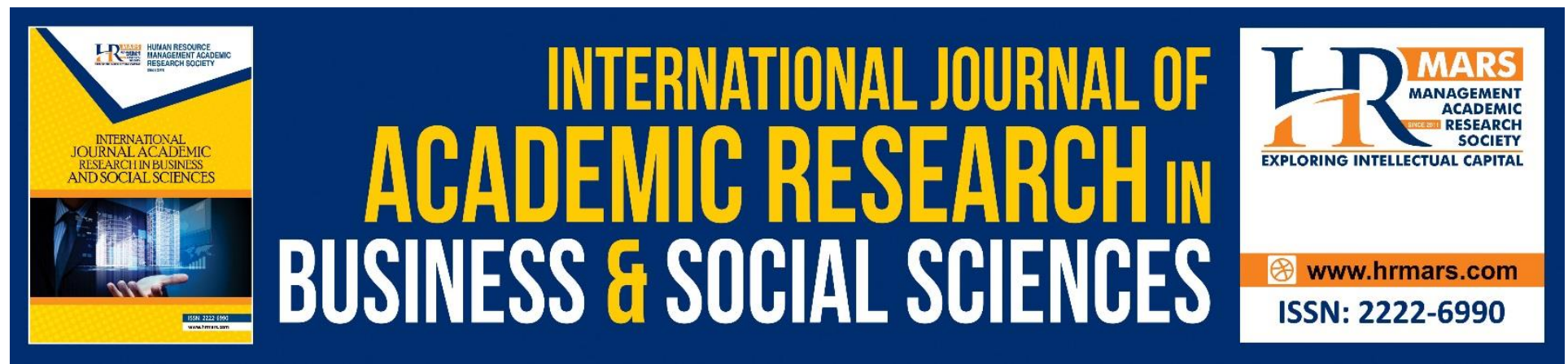

\title{
The Relationship between E-Service Quality and User Satisfaction Regarding the Use of Mobile Banking in The Banking Industry
}

Nor Afni Md Sari, Noor Azlina Mohamed Yunus, Norshima Humaidi and Azzura Nordin

To Link this Article: http://dx.doi.org/10.6007/IJARBSS/v8-i12/5287

DOI: $10.6007 /$ IJARBSS/v8-i12/5287

Received: 06 Nov 2018, Revised: 18 Dec 2018, Accepted: 28 Dec 2018

Published Online: 06 Jan 2019

In-Text Citation: (Sari, Yunus, Humaidi, \& Nordin, 2018)

To Cite this Article: Sari, N. A. M., Yunus, N. A. M., Humaidi, N., \& Nordin, A. (2018). The Relationship between EService Quality and User Satisfaction Regarding the Use of Mobile Banking in The Banking Industry. International Journal of Academic Research in Business and Social Sciences, 8(12), 1663-1676.

Copyright: @ 2018 The Author(s)

Published by Human Resource Management Academic Research Society (www.hrmars.com)

This article is published under the Creative Commons Attribution (CC BY 4.0) license. Anyone may reproduce, distribute, translate and create derivative works of this article (for both commercial and non-commercial purposes), subject to full attribution to the original publication and authors. The full terms of this license may be seen

at: http://creativecommons.org/licences/by/4.0/legalcode

Vol. 8, No. 12, 2018, Pg. 1663 - 1676

http://hrmars.com/index.php/pages/detail/IJARBSS

JOURNAL HOMEPAGE

Full Terms \& Conditions of access and use can be found at http://hrmars.com/index.php/pages/detail/publication-ethics 


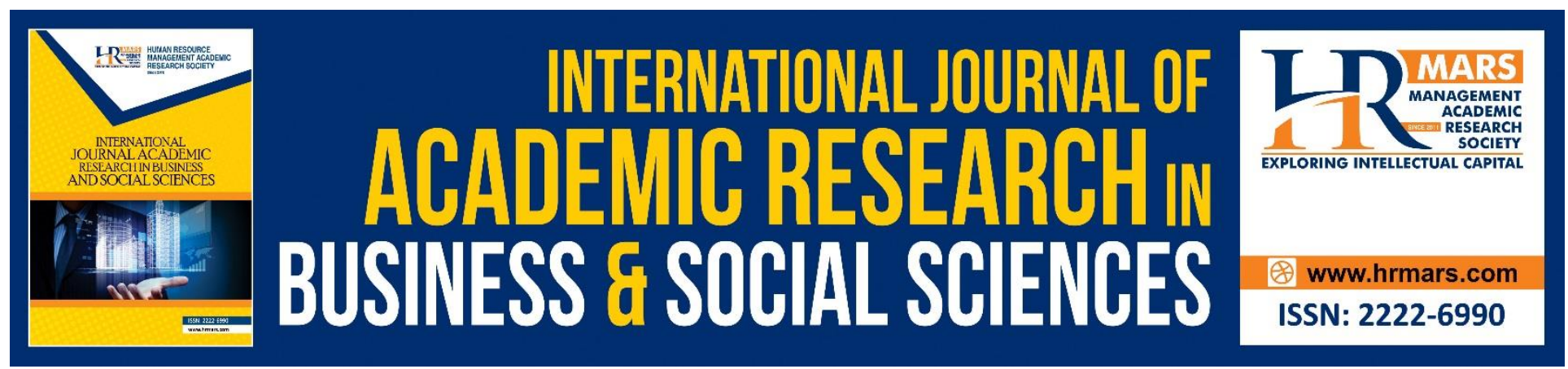

\title{
The Relationship between E-Service Quality and User Satisfaction Regarding the Use of Mobile Banking in The Banking Industry
}

\author{
Nor Afni Md Sari, Noor Azlina Mohamed Yunus, Norshima Humaidi \\ and Azzura Nordin
}

Faculty of Business and Management, Universiti Teknologi MARA Selangor, Malaysia

Corresponding Author: norshima958@puncakalam.uitm.edu.my

\begin{abstract}
Digital transformation is predominantly used in a business context, but it also impacts the banking industry, which is involved in tackling customer-centric sense of increasingly demanding customers who value speed, cost efficiencies and value-added innovative services. Therefore, the main purpose of this study is to determine the relationship between e-service quality and user satisfaction regarding the use of mobile banking in the banking industry. The scope of this study was the public users who have experienced using mobile banking services such as Bank Islam Internet Banking, CIMBClicks, MayBank2U, iRakyat, MyBSN and others. A total of 146 respondents were included in this study. The data was analysed using partial least square (PLS) techniques through the SmartPLS 3.0 software. The result indicated that there was a positive and significant relationship between e-service quality and user satisfaction in the use of mobile banking services. The most influential factor on user satisfaction was security followed by cost and ease of use, while reliability, responsiveness and usefulness were not significantly influential. Therefore, the researchers highly recommended for the banking industry to plan tremendous approaches and build up suitable actions by focusing on those particular e-service elements that represent significant outcomes that obviously leads to better business performance to the company. The researchers also recommended for future research to be carried out on other industries using different methodologies such as longitudinal method, enlarging the sample size and using the qualitative approach.
\end{abstract}

Keywords: User Satisfaction; E-Service Quality; Mobile Banking; Online Banking; Banking Industry.

\section{INTRODUCTION}

The increasing number of Internet users and the tremendous growth of mobile app by $270 \%$ (App Annie, 2015), have caused the banking industry to move forward to provide mobile banking 
service to their customers. Based on a survey done by the Malaysian Communications and Multimedia Commission (MCMC), the number of Internet users increased by $80 \%$ in $2016.50 \%$ of these Internet users carried out online shopping, which required them to transfer money online. Internet banking provides convenience to customers and encourages customers to conduct transactions more easily and efficiently through the banking website (Goh Mei Ling et al., 2016). On top of that, the Internet banking also helps banks to reduce their operating costs. Despite many benefits from online services, previous studies found that a large number of banks' customers were not willing to use the Internet banking services offered due to the services offered through Internet banking have yet to satisfy their customers (Zhang, Weng \& Zhu, 2018; Goh Mei Ling et al., 2016). Customer satisfaction is an important factor to help banks sustain their competitive advantages. Online service quality has an effect on online banking system performance and user satisfaction (Goh, Yeo, Lim, \& Tan, 2015). Therefore, this study aimed to determine the relationship of online service quality on user satisfaction towards the use of mobile banking services using the E-SERQUAL research model. The research model focused on six dimensions: Cost, Ease of Use, Reliability, Responsiveness, Security and Usefulness.

\section{LITERATURE REVIEW}

Users' satisfaction is important in all types of businesses, as the most effective way to increase and maintain user base is through achieving high user satisfaction (Kim, Meng, Kalinowski \& Shin, 2014). The provider must plan to continually improve the user experience of the service. In addition, by tracking user satisfaction, they can find out what users think about the service and which parts of it cause them problems (Measuring, 2017). User satisfaction is also considered as one of the most important and vital variables for long-time business success.

Nowadays the need for continuing activities and maintaining the competitive advantage is gaining attention among users (Mozaheb, Alamolhodaei, \& Ardakani, 2015). If the perceived performance matches or even exceeds the users' expectations of services, users are satisfied. If it does not, the users are dissatisfied (Taylor, 2016).

\section{E-SERQUAL RESEARCH MODEL}

\section{Cost}

Cost is one of the major factors that dominate users' acceptance of innovation. Aliyu, Rosmain, and Takala (2014) stated that the use of new technologies must be reasonably priced relative to the users. Otherwise, the acceptance of the new technology may not be practical from the standpoint of the customers.

Many Internet users are using smart phone compared to other devices such as desktop and laptop computers (Shetty, 2015). Anand, (2015) as cited in Shetty, (2015) said that even though Internet transactions will be dominated by mobile transactions, online banking would continue to be important and is growing at $30-40 \%$. Internet banking offers some of the lowest fees in banking. This can be done because online banking does not have the same level of costs as traditional banks. Therefore, the following hypothesis was constructed. 
INTERNATIONAL JOURNAL OF ACADEMIC RESEARCH IN BUSINESS AND SOCIAL SCIENCES

Vol. 8, No. 12, Dec, 2018, E-ISSN: 2222-6990 (c) 2018 HRMARS

H1: There is a positive relationship between the cost of E-service quality and user satisfaction towards the use of mobile banking services.

\section{Ease of Use}

According to Yoon (2015), ease of use is defined as free of effort using the new technology based on the individual's perception. In other words, perceived ease of use is the system is stress-free and effortless that someone believes with it (Oyeleye, Sanni \& Shittu, 2015). The easier it is for a user to interact with a system, the more likely he or she will find it useful.

A considerable amount of prior studies supported the significant effect of perceived ease of use on behavioural intention, either directly or indirectly through perceived usefulness (Nasri \& Zarai, 2014). Thus, if there is an ease of use in operation or process then, it is more likely for the customers to accept the online banking services which can be instrumental to the utilisation of technology and contribute to the individual by reducing transfer costs and improving work performance. Therefore, the following hypothesis was constructed.

H2: There is a positive relationship between ease of use of E-service quality and user satisfaction towards the use of mobile banking services.

\section{Reliability}

Reliability referred to providing the required service in a precise way and in line with advertised attributes (Camilleri et al., 2014). Iberahim, Taufik, Adzmir and Saharudin (2015) stated that reliability refers to the ability to deliver expected procedure at all times, how the problems faced by customer service are handled by the organisation, performing the right services for the first time, response was promised on a specific time and maintaining error-free record.

Based on online banking services, environment condition and technical reliability are equated to reliable design that is functional (Iberahim et. al, 2015). A proper functionality of the website has been involved due to the technical working are related to reliability (Khan et al., 2014). Therefore, the following hypothesis was constructed.

H3: There is a positive relationship between reliability of E-service quality and user satisfaction towards the use of mobile banking services.

\section{Responsiveness}

According to Jun and Cai (2001), cited in Camilleri et al. (2014) responsiveness refers to dealing with problems faced and the service of delivering a prompt response and convenient way to resolve the problem. Responsiveness is associated with the service of representatives for users. It measures the ability of the website to provide a specific time for service accomplishment given to the customers, always has the availability of representative on online for the response of customers' queries or complaints and provides online guarantees (Saqib, Irfanullah, Farhatullah, Naseem \& Ahmad, 2014). 
Other authors defined responsiveness as the ability for flexible and timely response to customer requirements (Ibrahim et al., 2015). Based on a statement by Jay and Barry (2014) cited in Iberahim et.al, (2015), it is stated that transformation of information technology has brought great changes in the business environment, and no other sector has been affected by advancements in technology as much as banking and financial institutions. Therefore, the following hypothesis was constructed.

H4: There is a positive relationship between responsiveness of E-service quality and user satisfaction towards the use of mobile banking services.

\section{Security}

The most challenging issue faced by customers in e-commerce world is privacy and security. Security in the form of keeping customer safe from an invasion of their privacy affects trust and satisfaction. Online service owners need to make guarantees in terms of privacy and security to gain the customers trust. Since security and trust are related, the norm of security violation may lead to losing users (Dixit \& Datta, 2017). About three in 10 mobile device owners in Malaysia prefer to visit physical banks rather than conduct banking activities on their mobile phone, and security was by far the biggest reason (Nielsen, 2016).

The main issue that banks face nowadays is privacy. Privacy includes providing security for the customers regarding their personal information. Data should not be shared and credit card information should be kept secure (Firdous, 2017). So it seems that while mobile banking has a reputation for a lack of security or privacy among some owners in Malaysia, many are still doing it. Therefore, the following hypothesis was constructed.

H5: There is a positive relationship between security of E-service quality and user satisfaction towards the use of mobile banking services.

\section{Usefulness}

The usefulness of Internet Banking is very crucial to the banking customers (Bashir \& Madhavaiah, 2014). Using Internet Banking, the customers can access their personal and business account information while avoiding a trip to the bank. In addition, they can check their balance whenever they need to, even if the bank is closed. Moreover, the customers can pay their bills online as well, which can save both time and money on parking and petrol (Aini, Zalinawati, Norudin \& Hayati, 2012). Users can easily use online banking if it is user-friendly, easy to operate and remember, and does not involve too much hassle to operate. The easier to use the technology, more useful it is perceived to be and more likely to be accepted by users (Bashir \& Madhavaiah, 2014). Therefore, the following hypothesis was constructed.

H6: There is a positive relationship between useful of E-service quality and user satisfaction towards the use of mobile banking services. 
Based on above literature discussion, the following research model was adapted as shown in FIGURE 1.

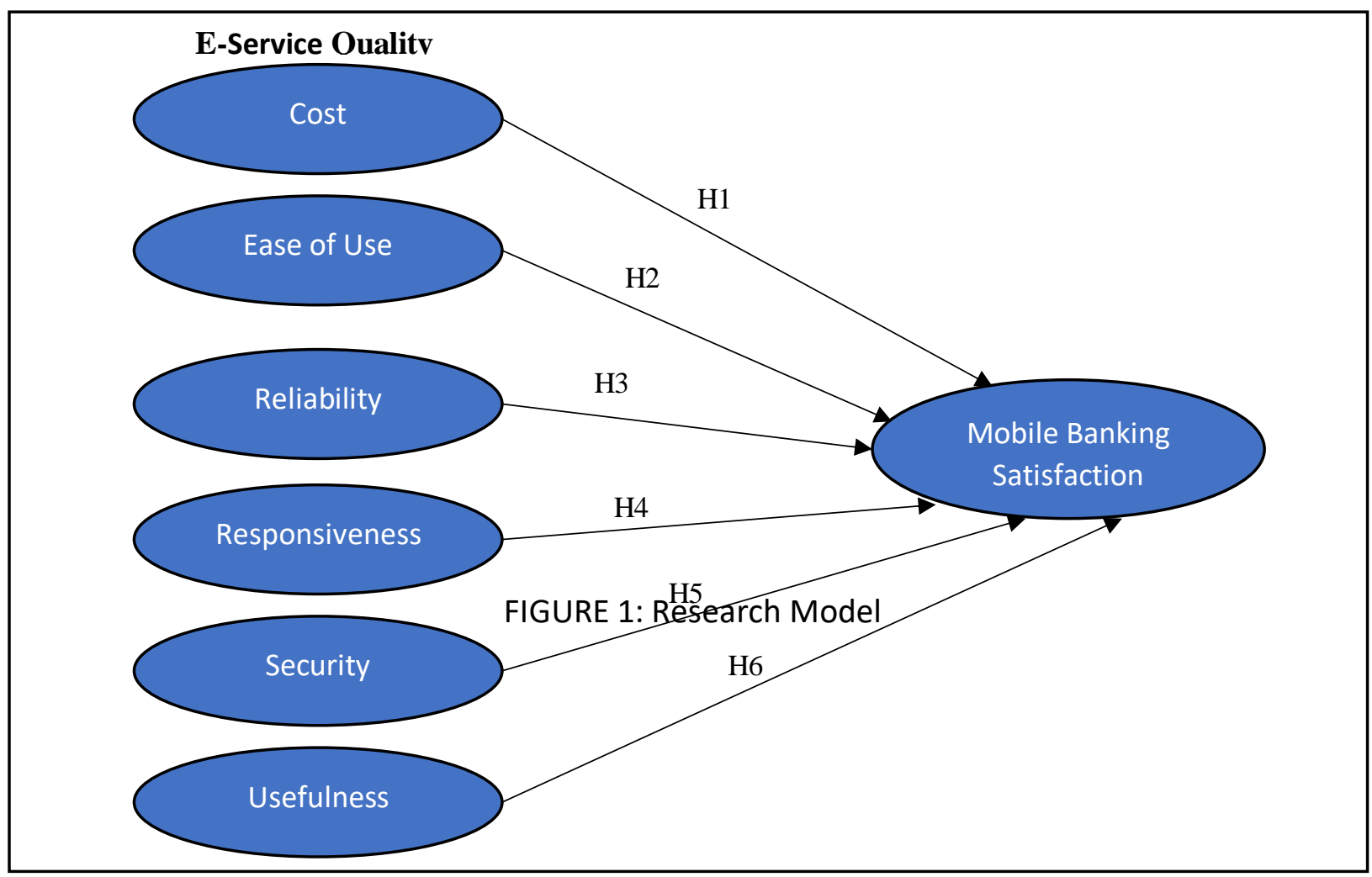

\section{METHODOLOGY}

The population of this study are dominantly public users who had experienced using mobile banking services such as Bank Islam IB, CIMBClicks, MayBank2U, iRakyat, MyBSN or others. This study employed the convenience sampling technique to select the respected respondent from the population. The Gpower software was used to determine the minimum sample size required. Since the model had a maximum of six (6) predictors (for the outcome E-SERQUAL Model), with the effect size as small as $(0.15)$ and power needed as 0.95 , the minimum sample size required was 146.

All questionnaires were hand delivered to the respondents. A cover letter and appropriate instruction were attached to the questionnaires. The questionnaire was distributed directly to the respondent and was collected right after they responded to the questionnaire.

The questionnaire consisted of three sections, which are:

\section{Section A: Demographic Information}

This section requires respondents to indicate their gender, age, education level, status, and income. The respondents can answer the multiple-choice questions by selecting one answer only. 
INTERNATIONAL JOURNAL OF ACADEMIC RESEARCH IN BUSINESS AND SOCIAL SCIENCES

Vol. 8, No. 12, Dec, 2018, E-ISSN: 2222-6990 @ 2018 HRMARS

\section{Section B: E-Service Quality}

In this section, the items have been adopted from An-Nasir et. al, (2014). It is reported that this survey has six dimensions to be measured, which are reliability, responsiveness, ease of use, cost, usefulness and security.

\section{Section C: User Satisfaction}

This section covered the questions related to user satisfaction toward online banking system.

\section{RESULT}

The demographic details show that the majority of the participants were male $(n=222)$ compared to female $(n=220)$. The majority of these respondents are Malay $(n=275)$, followed by Chinese $(n=73$, Indian $(n=56)$ and others $(n=38)$. Most of the respondents have income between RM1000 to RM5000 ( $n=282)$. The result also indicated that many of the respondents used mobile banking once in a month $(n=135)$. The details of the results are shown in TABLE 1.

TABLE 1: Demographic Details

\begin{tabular}{|c|c|c|c|}
\hline & Demographic Item & Frequency & Percentage \\
\hline \multirow[t]{2}{*}{ Gender } & Male & 222 & $50.2 \%$ \\
\hline & Female & 220 & $49.8 \%$ \\
\hline \multirow[t]{4}{*}{ Race } & Malay & 275 & $62.2 \%$ \\
\hline & Indian & 56 & $12.7 \%$ \\
\hline & Chinese & 73 & $16.5 \%$ \\
\hline & Others & 38 & $8.6 \%$ \\
\hline \multirow[t]{3}{*}{ Income } & $<$ RM1000 & 79 & $17.9 \%$ \\
\hline & RM1000 - RM5000 & 282 & $63.8 \%$ \\
\hline & $>$ RM5000 & 81 & $18.3 \%$ \\
\hline \multirow[t]{6}{*}{ Bank Provider } & Bank Islam & 62 & $14.0 \%$ \\
\hline & CIMBClicks & 149 & $33.7 \%$ \\
\hline & Maybank 2 U & 130 & $29.4 \%$ \\
\hline & iRakyat & 48 & $10.9 \%$ \\
\hline & MyBSN & 31 & $7.0 \%$ \\
\hline & Others & 22 & $5.0 \%$ \\
\hline \multicolumn{4}{|l|}{ Frequency of } \\
\hline \multirow[t]{4}{*}{ Use } & Daily & 46 & $10.4 \%$ \\
\hline & 2-4 times a week & 117 & $26.5 \%$ \\
\hline & Once a week & 144 & $32.6 \%$ \\
\hline & Once in a month & 135 & $30.5 \%$ \\
\hline
\end{tabular}




\section{Confirmatory Factor Analysis (CFA)}

The SmartPLS 3.0 software was used to analyse the data of the study. To test the CFA, a bootstrapping method of 500 resamples was used to determine the significance level of the loadings, weights and path coefficient. The CFA began with the assessment of the convergent and discriminant analysis. The results are shown in TABLE 2. The loadings of factor analysis yield the results of items exceeding the recommended value of 0.6. Two sets of convergent analyses were run in order to assess the composite reliability and average variance extracted (AVE) values. The composite reliability $(C R)$ values which is to show the degree to which the items indicated the latent construct, ranged from 0.837 to 0.910 . Hence, the composite reliability requirements are met since the values exceeded the recommended value of 0.7 . In addition, the average variance extracted was in the range of 0.508 and 0.670 . Moreover, this study shows that $37.3 \%$ of variance for mobile banking satisfaction is explained by E-Service Quality.

The next procedure was to assess the discriminant validity by examining the correlations between constructs and their square root of the average variance extracted. The results show that the square root of the AVE is greater than the correlation with other constructs as shown in TABLE 3. Thus, the measurement model reflects acceptable convergent and discriminant validity. 
INTERNATIONAL JOURNAL OF ACADEMIC RESEARCH IN BUSINESS AND SOCIAL SCIENCES

Vol. 8, No. 12, Dec, 2018, E-ISSN: 2222-6990 @ 2018 HRMARS

TABLE 2: Convergence Reliability and Validity Testing

\begin{tabular}{|c|c|c|c|c|c|c|c|}
\hline Item & Outer Loading & Mean & Standard Deviation & Cronbach Alpha & Composite Reliability & Average Variance Extracted & $\mathbf{R}^{2}$ \\
\hline Cost & & 3.906 & 0.665 & 0.791 & 0.855 & 0.541 & \\
\hline COST1 & 0.714 & & & & & & \\
\hline $\operatorname{cosT} 2$ & 0.739 & & & & & & \\
\hline cost3 & 0.725 & & & & & & \\
\hline COST4 & 0.771 & & & & & & \\
\hline COST5 & 0.729 & & & & & & \\
\hline Ease of Use & & 3.869 & 0.761 & 0.849 & 0.892 & 0.623 & \\
\hline EASE1 & 0.827 & & & & & & \\
\hline EASE2 & 0.763 & & & & & & \\
\hline EASE3 & 0.800 & & & & & & \\
\hline EASE4 & 0.775 & & & & & & \\
\hline EASE5 & 0.780 & & & & & & \\
\hline Reliability & & 3.825 & 0.707 & 0.804 & 0.864 & 0.560 & \\
\hline REAL1 & 0.770 & & & & & & \\
\hline REAL2 & 0.754 & & & & & & \\
\hline REAL3 & 0.752 & & & & & & \\
\hline REAL4 & 0.716 & & & & & & \\
\hline REAL5 & 0.747 & & & & & & \\
\hline Responsiveness & & 3.661 & 0.835 & 0.858 & 0.898 & 0.637 & \\
\hline RESP1 & 0.806 & & & & & & \\
\hline RESP2 & 0.815 & & & & & & \\
\hline RESP3 & 0.767 & & & & & & \\
\hline RESP4 & 0.802 & & & & & & \\
\hline RESP5 & 0.800 & & & & & & \\
\hline Security & & 4.034 & 0.803 & 0.877 & 0.910 & 0.670 & \\
\hline SEC1 & 0.824 & & & & & & \\
\hline SEC2 & 0.868 & & & & & & \\
\hline SEC3 & 0.813 & & & & & & \\
\hline SEC4 & 0.826 & & & & & & \\
\hline
\end{tabular}


INTERNATIONAL JOURNAL OF ACADEMIC RESEARCH IN BUSINESS AND SOCIAL SCIENCES

Vol. 8, No. 12, Dec, 2018, E-ISSN: 2222 -6990 @ 2018 HRMARS

\begin{tabular}{|c|c|c|c|c|c|c|c|}
\hline Item & Outer Loading & Mean & Standard Deviation & Cronbach Alpha & Composite Reliability & Average Variance Extracted & $\mathbf{R}^{2}$ \\
\hline SEC5 & 0.758 & & & & & & \\
\hline Usefulness & & 4.026 & 0.599 & 0.758 & 0.837 & 0.508 & \\
\hline USE1 & 0.763 & & & & & & \\
\hline USE3 & 0.707 & & & & & & \\
\hline USE4 & 0.672 & & & & & & \\
\hline Satisfaction & & 3.922 & 0.790 & 0.845 & 0.890 & 0.620 & 0.373 \\
\hline SAST1 & 0.687 & & & & & & \\
\hline SAST2 & 0.794 & & & & & & \\
\hline SAST3 & 0.820 & & & & & & \\
\hline SAST4 & 0.784 & & & & & & \\
\hline SAST5 & 0.842 & & & & & & \\
\hline
\end{tabular}


INTERNATIONAL JOURNAL OF ACADEMIC RESEARCH IN BUSINESS AND SOCIAL SCIENCES

Vol. 8, No. 12, Dec, 2018, E-ISSN: 2222-6990 @ 2018 HRMARS

TABLE 3: Discriminant Validity

\begin{tabular}{cccccccc}
\hline Construct & Cost & $\begin{array}{c}\text { Ease of } \\
\text { Use }\end{array}$ & Reliability & Responsiveness & Security & Usefulness & Satisfaction \\
\hline Cost & $\mathbf{0 . 7 3 6}$ & & & & & & \\
Ease of Use & 0.647 & $\mathbf{0 . 7 8 9}$ & & & & & \\
Reliability & 0.681 & 0.597 & $\mathbf{0 . 7 4 8}$ & & & & \\
Responsiveness & 0.662 & 0.733 & 0.619 & $\mathbf{0 . 7 9 8}$ & & \\
Security & 0.565 & 0.695 & 0.498 & 0.638 & $\mathbf{0 . 8 1 9}$ & \\
Usefulness & 0.665 & 0.573 & 0.607 & 0.507 & 0.537 & $\mathbf{0 . 7 1 2}$ & $\mathbf{0 . 7 8 7}$ \\
Satisfaction & 0.479 & 0.517 & 0.412 & 0.431 & 0.569 & 0.398 & \\
\hline
\end{tabular}

\section{Hypothesis Testing Results}

The result identified that there is a positive and significant relationship between e-service quality and user satisfaction regarding the use of mobile banking services. The most influential factor on user satisfaction is security $(\beta=0.382, t=5.636)$ followed by cost $(\beta=0.181, t=3.586)$ and ease of use $(\beta=$ $0.172, t=2.331)$. However, there is no significant influence among reliability $(\beta=0.061, t=1.127)$, responsiveness $(\beta=-0.088, t=1.384)$ and usefulness $(\beta=-0.018, t=0.388)$ on user satisfaction. Therefore, $\mathrm{H} 1, \mathrm{H} 2$ and $\mathrm{H} 5$ are accepted while $\mathrm{H} 3, \mathrm{H} 4$ and $\mathrm{H} 6$ are rejected.

In addition, the Stone-Geisser approach is used to assess whether the predictor variable has a substantive influence on the mobile banking service satisfaction by exploring the effect of $\mathbf{f}^{2}$. According to Chin (1998), the higher the $\mathbf{f}^{2}$, the greater the influence of exogenous construct where in this case, mobile banking service satisfaction with the values of $0.02,0.15$ and 0.35 can be respectively regarded as small, medium or large effect respectively. Thus, the results of effect size shows that security, cost and ease of use have smaller effects on user satisfaction towards the use of mobile banking services. The details of the result are as shown in TABLE 4.

TABLE 4: Hypothesis Testing

\begin{tabular}{ccccccc}
\hline $\begin{array}{c}\text { Hypothesi } \\
\text { S }\end{array}$ & Relationship & $\boldsymbol{\beta}$ & STDEV & t-value & $\begin{array}{c}\text { value } \\
\mathbf{f}^{\mathbf{2}}\end{array}$ \\
\hline $\boldsymbol{H 1}$ & Cost -> Satisfaction & 0.181 & 0.050 & 3.586 & $\mathbf{0}$ & 0.019 \\
$\boldsymbol{H} \mathbf{2}$ & Ease of Use -> Satisfaction & 0.172 & 0.074 & 2.331 & $\mathbf{0 . 0 1 0}$ & 0.016 \\
H3 & Reliability -> Satisfaction & 0.061 & 0.054 & 1.127 & 0.130 & 0.003 \\
H4 & Responsiveness -> Satisfaction & -0.088 & 0.063 & 1.384 & 0.083 & 0.005 \\
H5 & Security -> Satisfaction & 0.382 & 0.068 & 5.636 & $\mathbf{0}$ & $\mathbf{0 . 1 0 7}$ \\
H6 & Usefulness -> Satisfaction & -0.018 & 0.047 & 0.388 & 0.349 & 0 \\
\hline
\end{tabular}

\section{CONCLUSION}

This study is meant to investigate the relationship between e-service quality and user satisfaction towards the use of mobile banking in banking industry. Based on the data analysis, there is a positive and significant relationship between e-service quality and user satisfaction towards the use of mobile banking services. Vital dimensions of e-service quality, namely security, cost and ease of use, significantly contribute to user satisfaction. Conversely, reliability, responsiveness and usefulness are 
not significant predictors on user satisfaction. These dimensions are not significant predictors on user satisfaction in the banking industry due to the great technology approach employed by the companies.

\section{A. Managerial Implication}

Based on the findings, the current study establishes that e-service quality significantly influences user satisfaction towards the use of mobile banking services. Mainly, the elements of e-service quality such as security, cost and ease of use significantly influence user satisfaction. According to their significance, the most influential factor on user satisfaction is security, followed by cost and ease of use. As a result, the management in the banking industry should deliberate heavily in delivering excellent e-service quality particularly through the security element, because the excellent e-service quality that the customer experienced may be able to enhance their satisfaction without ignoring the other dimensions such as cost and ease of use. Gaining user satisfaction will be a valued advantage to counter competitive challenges especially in the era of Industry Revolution 4.0 (IR4.0). In IR4.0, it is accepted that e-service quality is becoming the utmost significant aspect of business accomplishment mainly for the banking service providers to attain competitive edge, and establish user satisfaction as well as user loyalty.

\section{B. Research Limitations and Future Suggestions}

It is recommended for further studies to be carried out in other areas such as hospitality and others to investigate whether there are any similarities in the findings to indicate that e-service quality critically and significantly influences user satisfaction. Furthermore, future research should be conducted using different methodologies such as by utilising the longitudinal method in investigating the relationship between e-service quality and user satisfaction. Additionally, future researchers also can utilise the qualitative approach namely interviews in gathering the research data on the issues of interest. Lastly, future researchers should enlarge the sample size to ensure the generalisability of the findings.

\section{ACKNOWLEDGMENT}

The authors would like to express the deepest appreciation to all those who provided the support to complete this study. The co-operation is much appreciated. The authors also gratefully acknowledge the contribution of the Faculty of Business and Management, Universiti Teknologi MARA (UiTM) for the on-going support especially for the research grants, which contributed greatly to the excellence of this study and results.

\section{REFERENCES}

Aini, H. N., Zalinawati, A., Norudin, M., \& Hayati, H. N. (2012). Acceptance towards the Use of Internet Banking Services of Cooperative Bank. Acceptance towards the Use of Internet Banking Services of Cooperative Bank, 2(2), 58-70.

Aliyu, A. A., Rosmain, T., \& Takala, J. (2014). Online Banking and Customer Service Delivery in Malaysia: Data Screening and Preliminary Findings. Procedia - Social and Behavioral Sciences, 129, 562-570. 
INTERNATIONAL JOURNAL OF ACADEMIC RESEARCH IN BUSINESS AND SOCIAL SCIENCES

Vol. 8, No. 12, Dec, 2018, E-ISSN: 2222-6990 @ 2018 HRMARS

An-Nasir, A., Almsafir, M., \& Alshoura, H. (2014). E-Service Quality: Conceptual Approach. Journal of Advanced Social Research, 4(4), 01-9.

App Annie (2015). Complete app market to uncover opportunities without the guesswork. Available from https://www.appannie.com/en/platform/intelligence. Retrieve on 25 Jun 2018.

Bashir, I., \& Madhavaiah, C. (2015). Consumer attitude and behavioural intention towards Internet banking adoption in India. Journal of Indian Business Research, 7(1), 67-102.

Camilleri, S., Cortis, J., \& Fenech, M. (2014). Service Quality and Internet Banking Perceptions of Maltese Retail Bank Customers. Bank of Valletta Review, 48, 1-17.

Dixit, N., \& Datta, S. K. (2017). Acceptance of E-banking among Adult Customers: An Empirical Investigation in India. Journal of Internet Banking and Commerce Journal of Internet Banking and Commerce. Retrieved May 25, 2017, from http://www.icommercecentral.com/openaccess/acceptance-of-ebanking-among-adult-customers-an-empirical-investigation-in-india1-17.php?aid=38370

Firdous, S. (2017). Impact of internet banking service quality on customer satisfaction. Journal of Internet Banking and Commerce, 22(1), 1-17.

Iberahim, H., Taufik, N. M., Adzmir, A. M., \& Saharuddin, H. (2016). Customer Satisfaction on Reliability and Responsiveness of Self Service Technology for Retail Banking Services. Procedia Economics and Finance, 37, 13-20.

Khan, M. S., Khan, I., Khan, F., Yar, N. B., \& Khan, A. A. (2014). Relationship between Service Quality and Customer Satisfaction: A study of internet banking. Industrial Engineering Letters, 4(4), 70-88.

Kim, S., Meng, J., Kalinowski, J. \& Shin, D. (2014). The Development and Validation of an End-User Satisfaction Measure in A Student Laptop Environment, American Journal of Business Education, 7(2), 157-170.

MCMC 2017 Internet Users Survey 2017 Report Retrieved on 20 Jun 2018 https://www.mcmc.gov.my/skmmgovmy/media/General/pdf/MCMC-Internet-UsersSurvey-2017.pdf

Measuring. (2016). Retrieved July 06, 2017, from https://www.gov.uk/service-manual/measuringsuccess/measuring-user-satisfaction

Mozaheb, A., Alamolhodaei, S. M., \& Ardakani, M. F. (2015). Effect of Customer Relationship Management (CRM) on Performance of Small-Medium Sized Enterprises (SMEs) Using Structural Equations Model (SEM). International Journal of Academic Research in Accounting, Finance and Management Sciences, 5(2), 42-52.

Nasri, W., \& Zarai, M. (2014). Empirical Analysis of Internet Banking Adoption in Tunisia. Asian Economic and Financial Review, 4(12), 1812-1825.

Goh Mei Ling, Yeo Sook Fern, Lim Kah Boon and Tan Seng Huat (2016), Understanding Customer Satisfaction of Internet Banking: A Case Study In Malacca, Procedia Economics and Finance, $37,80-85$.

Goh, M., Yeo, S., Lim, K., \& Tan, S. (2015). Understanding Customer Satisfaction of Internet Banking: A Case Study in Malacca. Procedia Economics and Finance, 37, 80-85. 
Shetty, M. (2015). Low development cost sparks boom in mobile banking. Gadget Now. Retrieved 10 April 2017, from http://www.gadgetsnow.com/tech-news/Facebook-COO-Sheryl-Sandbergjoins-SurveyMonkey-board/articleshow/47972333.cms

Oyeleye, O., Sanni, M., \& Shittu, T. (2015). An Investigation of the Effects of Customers Educational Attainment on their Adoption of E-banking in Nigeria. The Journal of Internet Banking and Commerce, 20-133.

Yoon, C. (2015). Exploring Factors That Affect Usefulness, Ease of Use, Trust, And Purchase Intention in The Online Environment. International Journal of Management \& Information Systems, 19(1), 21-36.

Zhang, Y., Weng, Q. and Zhua, N. (2018). The relationships between electronic banking adoption and its antecedents: A meta-analytic study of the role of national culture. International Journal of Information Management, 40, page 76-87. 